\section{Prevalence of Citrus Tristeza Virus in Florida Citrus Nurseries and Scion Groves}

\author{
Charles A. Powell, Robert R. Pelosi, and Phyllis A. Rundell \\ University of Florida, Institute of Food and Agricultural Sciences, Indian River \\ Research and Education Center, 2199 S. Rock Road, Fort Pierce, FL 34945
}

Additional index words. certification, clean stock, Citrus sinensis

\begin{abstract}
None of 4190 sweet orange [Citrus sinensis (L.) Osb.] nursery trees of 'Hamlin', 'Midsweet', 'Navel', and 'Valencia'sampled from five Florida citrus nurseries were infected with a decline-inducing isolate of citrus tristeza virus (CTV) as judged by enzyme-linked immunosorbent assay (ELISA) using isolate-specific monoclonal antibodies. Two of the nurseries had a relatively high level of infection $(37 \%$ to $100 \%$ of composite samples containing tissue from 10 trees) with nondecline-inducing (mild) isolates of CTV, depending on the cultivar. Three of the nurseries had a lower incidence of mild CTV $(0 \%$ to $22 \%$ of 10 tree composite samples). No nursery was CTV-free. ELISA of individual trees used as budwood sources by the nurseries revealed that one tree out of 260 tested contained decline-inducing CTV, and 83 contained mild CTV. These results suggest that the budwood certification program adopted in 1997 has virtually eliminated decline-inducing CTV from commercial budwood supplies.
\end{abstract}

Citrus tristeza virus (CTV) causes economically important disease worldwide wherever citrus is grown (Bar-Joseph et al., 1981, 1989; Garnsey and Lee, 1988). The virus causes a variety of field symptoms including slow decline, quick decline, stunting, and/or stem-pitting of the scion depending on the virus isolate, host, environmental conditions, and age of the tree when infected. The first three symptom types occur in citrus grafted onto sour orange (Citrus aurantium $\mathrm{L}$.) or related rootstocks, while the stem-pitting symptoms mostly occur in sweet orange, grapefruit (C.paradisi Macf.), or both, regardless of the rootstock.

Probably the most effective means of reducing $\mathrm{CTV}$-induced disease is through a certification program in which budwood source trees are tested for and maintained free of disease-inducing CTV. Such a program requires regular analysis of the source trees using reliable, rapid, and low cost techniques. The technique that best meets these criteria, and is used in most certifications, is enzymelinked immunosorbent assay (ELISA). In Florida, the assay is performed using the decline isolate-specific monoclonal antibody (MAb) MCA13 (Permar et al., 1990). This MAb reacts with most decline-inducing CTV in Florida, but does not react with nondeclineinducing CTV (Permar and Garnsey, 1991) The MCA13 based discrimination between decline- and nondecline-inducing isolates of CTV outside of Florida may not be effective (Cambra et al., 1993).

In 1993, it was reported that between $4 \%$ and $76 \%$ of the trees in five Florida citrus nurseries, and $35 \%$ of Florida budwood source trees tested, were infected with decline-inducing CTV (Powell and Pelosi, 1993). As a result

Received for publication 4 Feb. 2002. Accepted for publication 27 June 2002. Florida Agricultural Expt. Station Journal Series no. R-08627. introduction of stem-pitting CTV into commercial citrus, a mandatory budwood program was established in Florida in 1997. This program required that commercial citrus nursery stock in Florida be propagated from certified trees which had assayed negative for declineinducing CTV by ELISA using MCA13.

It was hoped the program would reduce the incidence of severe CTV in Florida's nursery stock and budwood sources. We have conducted another survey to test this hypothesis.

\section{Materials and Methods}

Five Florida citrus nurseries, capable of producing 500,000 trees annually, and representing the south-central and southeastern regions of the state, were selected and designated A, B, C, D, and $\mathrm{E}$. Three of these nurseries (A, B, and D) were the same as those sampled in 1991 (Powell and Pelosi, 1993). Ateach nursery, samples were taken from both their nursery stock (9-month-old budded sweet orange trees ready for sale) and their scion block (trees that were used directly as budwood sources or were used as the source of buds for increase blocks which were in turn used as budwood sources for nursery stock). The sweet orange cultivars sampled were 'Hamlin', 'Midsweet', 'Navel', and 'Valencia'. In three nurseries, the ready-for-sale stock was grown in greenhouses; at the other two nurseries, the stock was planted in the field. One nursery kept its scion block in an insect-free screenhouse, three nurseries had their scion block in the field, and one nursery had scion trees in both a screenhouse and in the field.

Sampling of the nursery stock followed the procedures for sampling a percentage of the trees and assaying bulked samples as outlined by Hughes and Gottwald (2001). Greenhouse container-grown nursery stock was sampled by walking around the perimeter of the greenhouse of reports like this and concerns about the bench, collecting a twig of the youngest tissue from every $4^{\text {th }}$ to $6^{\text {th }}$ tree depending on the number of trees in each bench row. Ten twigs from 10 consecutive samplings were combined and used as the assay tissue. Field-grown nursery stock was sampled by selecting two rows, at random, from each block and walking down the row, collecting a young twig from every 10th tree. Ten twigs collected from consecutive collections were combined and used as the assay sample. Control assay samples were one twig from a T36 (severe CTV), T30 (mild CTV), or uninfected sweet orange tree combined with nine twigs from uninfected trees. Containergrown and field-grown nursery stock were replicated by bench or row, respectively.

Scion blocks were sampled by collecting five twigs from different regions of the canopy of each tree. These five twigs were combined and used as the assay sample. Twigs from different trees were not combined. Control assay samples were five similarly collected twigs from T36, T30, or uninfected trees.

About $0.1 \mathrm{~g}$ of each twig, in each composite sample, was processed using a Kleco pulverizer (Kinetic Laboratory Equipment Co., Visailia, Calif.) in $7.5 \mathrm{~mL}$ of TPBS buffer $(0.015 \mathrm{M}$ sodium phosphate $0.15 \mathrm{M} \mathrm{NaC} 1,0.05 \%$ Tween $20, \mathrm{pH}$ 7.4). ELISA was performed as previously described (Powell et al., 1992), except monoclonal antibody $17 \mathrm{G} 11$ was used as the strain nonspecific second antibody.

\section{Results}

Nursery stock. Many of the nursery trees (30\% of 10-tree composite samples had at least one tree infected) were infected with a nondecline-inducing (mild) isolate CTV as shown by reaction with MAb 17G11, but not MAb MCA13 (Table 1). The amount of infection varied considerably among citrus cultivars and among nurseries. For example, the overall percentage of mild CTV infected samples (grouping all cultivars together) from nursery $\mathrm{C}$ was $3 \%$, and only in 'Valencia', while $88 \%$ of the samples collected from nursery D were positive. The results were expected since most nurseries are either indifferent towards the presence of mild CTV isolates or deliberately propagate the mild isolates as potential crossprotecting agents.

None of the 419 10-tree composite samples reacted with MAb MCA13 in ELISA (Table 1). This suggests that of 4,190 nursery trees assayed, all were free of severe CTV isolates detectable by ELISA. This compares to a $4 \%$ to $76 \%$ (depending on the nursery) severe CTV infection rate reported in 1993 (Powell and Pelosi, 1993).

Scion blocks. ELISA of individual scion block trees used by the five nurseries showed a combined mild CTV infection level of $32 \%$ (Table 2). This was similar to the infection rate found in the nursery stock. As with the nursery stock, there was also considerable difference among nurseries. Only one nursery had all its scion trees free of CTV. This nursery kept its budwood in a screenhouse.

Decline-inducing CTV was detected by ELISA using MAb MCA13 in only one bud- 
Table 1. Percentage of samples from five Florida nurseries infected with mild or severe isolates of citrus tristeza virus (CTV).

\begin{tabular}{|c|c|c|c|c|c|c|}
\hline \multirow[b]{2}{*}{ Nursery } & \multirow[b]{2}{*}{$\begin{array}{l}\text { Planting } \\
\text { type }\end{array}$} & \multirow[b]{2}{*}{ Cultivar } & \multirow{2}{*}{$\begin{array}{c}\text { No. of 10-tree } \\
\text { composite samples } \\
\text { assayed }\end{array}$} & \multicolumn{3}{|c|}{ CTV incidence ${ }^{z}$} \\
\hline & & & & $\begin{array}{c}\text { Severe }^{y} \\
(\%)\end{array}$ & $\begin{array}{l}\operatorname{Mild}^{\mathrm{x}} \\
(\%)\end{array}$ & $\begin{array}{c}\text { Virus } \\
\text { negative }(\%)\end{array}$ \\
\hline \multirow[t]{4}{*}{$\overline{\mathrm{A}}$} & Greenhouse & Hamlin & 27 & $0 \pm 0$ & $56 \pm 4$ & $44 \pm 4$ \\
\hline & & Midsweet & 6 & $0 \pm 0$ & $50 \pm 0$ & $50 \pm 0$ \\
\hline & & Navel & 23 & $0 \pm 0$ & $78 \pm 14$ & $22 \pm 14$ \\
\hline & & Valencia & 16 & $0 \pm 0$ & $37 \pm 15$ & $63 \pm 15$ \\
\hline \multirow[t]{3}{*}{ B } & Greenhouse & Hamlin & 20 & $0 \pm 0$ & $0 \pm 0$ & $100 \pm 0$ \\
\hline & & Midsweet & 20 & $0 \pm 0$ & $0 \pm 0$ & $100 \pm 0$ \\
\hline & & Valencia & 20 & $0 \pm 0$ & $5 \pm 10$ & $95 \pm 10$ \\
\hline \multirow[t]{4}{*}{$\mathrm{C}$} & Greenhouse & Hamlin & 47 & $0 \pm 0$ & $0 \pm 0$ & $100 \pm 0$ \\
\hline & & Midsweet & 3 & $0 \pm 0$ & $0 \pm 0$ & $100 \pm 0$ \\
\hline & & Navel & 8 & $0 \pm 0$ & $0 \pm 0$ & $100 \pm 0$ \\
\hline & & Valencia & 64 & $0 \pm 0$ & $12 \pm 5$ & $88 \pm 5$ \\
\hline \multirow[t]{4}{*}{ D } & Field & Hamlin & 21 & $0 \pm 0$ & $96 \pm 8$ & $4 \pm 8$ \\
\hline & & Midsweet & 25 & $0 \pm 0$ & $88 \pm 18$ & $12 \pm 18$ \\
\hline & & Navel & 7 & $0 \pm 0$ & $100 \pm 0$ & $0 \pm 0$ \\
\hline & & Valencia & 21 & $0 \pm 0$ & $67 \pm 9$ & $33 \pm 9$ \\
\hline \multirow[t]{4}{*}{$\mathrm{E}$} & Field & Hamlin & 33 & $0 \pm 0$ & $21 \pm 5$ & $79 \pm 5$ \\
\hline & & Midsweet & 21 & $0 \pm 0$ & $0 \pm 0$ & $100 \pm 0$ \\
\hline & & Navel & 3 & $0 \pm 0$ & $0 \pm 0$ & $100 \pm 0$ \\
\hline & & Valencia & 34 & $0 \pm 0$ & $18 \pm 10$ & $82 \pm 10$ \\
\hline
\end{tabular}

${ }^{2}$ Percentage of samples positive for CTV by ELISA. Each sample consisted of a composite collected from 10 different nursery trees.

${ }^{y}$ Sample extract reacted with MAb MCA13 by ELISA.

${ }^{x}$ Sample extract reacted with MAb 17G11 by ELISA, but not by MAb MCA13. wood source tree out of 247 tested (Table 2). This tree has since been removed.

\section{Discussion}

In 1993, it was reported that several of Florida's citrus nurseries had a high level of decline-inducing CTV in their nursery stock and scion groves (Powell and Pelosi, 1993). Since then, a mandatory budwood certification program has been implemented requiring that budwood source trees test negative for decline-inducing CTV by ELISA using MAb MCA13.

There are limitations in detecting declineinducing CTV by ELISA using MCA13. It has been demonstrated that sweet orange and grapefruit that are infected with both decline-inducing and nondeclining isolates of CTV may carry the decline-inducing eludes detection by ELISA using MCA13. The decline-inducing isolate can be detected by other methods such as in situ immunoassay (Lin etal., 2000, 2002) or grafting to indicators (Powell et al., 2003). It is possible that some of the nursery stock and scion grove trees assayed may contain decline-inducing CTV that is not detectable using MCA13 ELISA. This uncertainty must be resolved by further experimentation.

In spite of these drawbacks, our results indicate that this program has been highly successful in reducing the incidence of decline-inducing CTV in Florida nursery stock. No decline-inducing CTV was detected in isolate at a concentration or distribution that

Table 2. Infection of scion block trees from five Florida citrus nurseries with severe or mild isolates of citrus tristeza virus (CTV).

\begin{tabular}{|c|c|c|c|c|c|c|}
\hline \multirow[b]{2}{*}{ Nursery } & \multirow{2}{*}{$\begin{array}{c}\text { Planting } \\
\text { type }\end{array}$} & \multirow{2}{*}{$\begin{array}{c}\text { Cultivar } \\
\text { tested }\end{array}$} & \multirow{2}{*}{$\begin{array}{c}\text { No. trees } \\
\text { tested }\end{array}$} & \multicolumn{3}{|c|}{ CTV incidence ${ }^{z}$} \\
\hline & & & & Severe & Mild & Virus negative \\
\hline \multirow[t]{4}{*}{$\overline{\mathrm{A}}$} & Screenhouse & Hamlin & 2 & 0 & 0 & 2 \\
\hline & & Midsweet & 6 & 0 & 0 & 6 \\
\hline & & Navel & 2 & 0 & 0 & 2 \\
\hline & & Valencia & 6 & 0 & 0 & 6 \\
\hline \multirow[t]{4}{*}{ B } & Field & Hamlin & 25 & 0 & 2 & 23 \\
\hline & & Midsweet & 25 & 0 & 0 & 25 \\
\hline & & Navel & 10 & 0 & 0 & 10 \\
\hline & & Valencia & 25 & 0 & 2 & 23 \\
\hline \multirow[t]{4}{*}{$\mathrm{C}$} & Field & Hamlin & 5 & 0 & 1 & 4 \\
\hline & & Midsweet & 3 & 0 & 0 & 3 \\
\hline & & Navel & 1 & 0 & 1 & 0 \\
\hline & & Valencia & 3 & 0 & 3 & 0 \\
\hline \multirow[t]{4}{*}{$\mathrm{D}$} & Field & Hamlin & 10 & 0 & 10 & 0 \\
\hline & & Midsweet & 10 & 0 & 9 & 1 \\
\hline & Screenhouse & Navel & 7 & 1 & 7 & 0 \\
\hline & & Valencia & 29 & 0 & 20 & 9 \\
\hline \multirow[t]{4}{*}{$\mathrm{E}$} & Field & Hamlin & 33 & 0 & 0 & 33 \\
\hline & & Midsweet & 21 & 0 & 0 & 21 \\
\hline & & Navel & 3 & 0 & 0 & 3 \\
\hline & & Valencia & 34 & 0 & 28 & 6 \\
\hline
\end{tabular}

${ }^{\mathrm{z}}$ Number of trees testing negative or positive for severe or mild CTV isolates, based on ELISA reactions with monoclonal antibodies. nursery stock and only one MCA13 positive scion block tree was found. This is in spite of the introduction of the brown citrus aphid (Toxoptera citricida Kirkaldy) into Florida.

The fact the one scion grove Navel tree was found to be infected with decline-inducing CTV in nursery $\mathrm{C}$, but no decline-inducing CTV was detected in Navel nursery stock in the same nursery is not contradictory. The infected tree, which was on sour orange rootstock did not appear completely healthy, and the nurseryman informed us it had not been used as a budwood source that year.

Hughes and Gottwald (2001) have developed survey methods for assessment of CTV in citrus nurseries. These methods, which were used in this survey, allowed us to rapidly assess large numbers of trees to derive an overall picture of CTV prevalence in both greenhouse, container-grown, and field-grown nursery stock.

\section{Literature Cited}

Bar-Joseph, M., R. Marcus, and R.F. Lee. 1989. The continuous challenge of citrus tristeza virus control. Ann. Rev. Phytopathol. 27:291-316.

Bar-Joseph, M., C.N. Roistacher, S.M. Garnsey, and D.J. Gumpf. 1981. A review on tristeza, an ongoing threat to citriculture. Proc. Intl. Soc. Citricult. 1:419-422.

Cambro, M., E. Camarasa, M.T. Gorris, S.M. Garnsey, D.J. Gumpf, and M.C. Tsai. 1993. Epitope diversity of citrus tristeza virus isolates in Spain. p. 33-38. Proc. $12^{\text {th }}$ Conf. IOCV. IOCV, Riverside.

Garnsey, S.M. and R.F. Lee. 1988. Tristeza, p. 48-50. In: J.O. Whiteside, S.M. Garnsey, and L.W. Timmer (eds.). Compendium of citrus diseases. APS Press.

Hughes, G. and T.R. Gottwald. 2001. Survey methods for assessment of citrus tristeza virus incidence in citrus nurseries. Plant Dis. 85:910-918.

Lin, Y., R.H. Brlansky, and C.A. Powell. 2002. Inefficient transmission of citrus tristeza virus from grapefruit by single brown citrus aphids.HortScience 37:936-939.

Lin, Y., P.A. Rundell, L. Xie, and C.A. Powell. 2000. In situ immunoassay for detection of citrus tristeza virus. Plant Dis. 84:937-940.

Permar, T.A. and S.M. Garnsey. 1991. Comparison of biological indexing and immunological assays for identifying severe Florida isolates of citrus tristeza virus. p. 56-59. Proc. $11^{\text {th }}$ Conf. IOCV. IOCV, Riverside.

Permar, T.A., S.M. Garnsey, D.J. Gumpf, and R.F. Lee. 1990. A monoclonal antibody that discriminates strains of citrus tristeza virus. Phytopathology 80:224-228.

Powell, C.A. and R.R. Pelosi. 1993. Prevalence of severe strains of citrus tristeza virus in Florida citrus nurseries. HortScience 28:699-700.

Powell, C.A., R.R. Pelosi, and M. Cohen. 1992. Superinfection of orange trees containing mild isolates of citrus tristeza virus with severe isolates of citrus tristeza virus. Plant Dis. 76:141-144.

Powell, C.A., P.A. Rundell, and R.R. Pelosi. 2003. Suppression of decline-inducing isolates of citrus tristeza virus by nondecline-inducing isolates. HortScience 38:62-64. 